\title{
Rosa gallica Flower Oil
}

National Cancer Institute

\section{Source}

National Cancer Institute. Rosa gallica Flower Oil. NCI Thesaurus. Code C107358.

The oil extracted from the flowers of Rosa gallica. Rose oil is used as a frangrance component. 